\title{
Cotton in West and Central Africa: from the agricultural revolution to the agro-ecological transition
}

\author{
Mamy Soumaré ${ }^{1, *}$, Michel Havard ${ }^{2,4, \dagger}$ and Bruno Bachelier ${ }^{3,4}$ \\ ${ }^{1}$ Institut d'Economie Rurale, Université des Sciences Sociales et de Gestion, Bamako, Mali \\ 2 CIRAD, UMR Innovation, IER, Bamako, Mali \\ 3 CIRAD, UPR AIDA, F-34398 Montpellier, France \\ ${ }^{4}$ Univ Montpellier, Montpellier, France
}

\begin{abstract}
Since the 1970s, cotton has been a driving force in the transformation of agricultural production systems and a key element in local economies in the savannah areas of West and Central Africa (WCA). However, the sustainability of cotton-based production systems is often debated because of their effects on soils and the negative impacts of chemical pest control on the environment and human health. Through drastic reforms, the WCA cotton sector overcame the crises, showing its resilience. Today, research should be mobilized to help the sector tackle the major challenges: i) economic (price volatility, producers' incomes), ii) social (inclusion of vulnerable groups, role of women and young people, etc.) and iii) environmental (impact of pesticides, soil degradation, etc.) and linked to climate change. The articles published in this issue present some results and perspectives of research work, which can help improving the sustainability of cotton systems in WCA, open paths towards an agro-ecological transition and address the new challenges.
\end{abstract}

Keywords: Cotton / rural development / agro-ecology / sustainability / West and Central Africa

Résumé - Le coton en Afrique de l'Ouest et du Centre : de la révolution agricole à la transition agroécologique. Depuis les années 1970, le coton a été un moteur dans la transformation des systèmes de production agricole et un élément structurant des économies locales dans les savanes d'Afrique de l'Ouest et du Centre (AOC). Cependant, la durabilité des systèmes de production à base de coton est souvent mise en débat à cause de leurs effets sur les sols et des impacts négatifs de la lutte chimique sur l'environnement et la santé humaine. Au moyen de réformes drastiques, le secteur coton en AOC a surmonté les crises, montrant sa capacité de résilience. Aujourd'hui, ce secteur est confronté à des défis importants sur lesquels la recherche doit se mobiliser : i) économiques (volatilité des prix, revenus des producteurs, bien-être des communautés), ii) sociaux (inclusion des couches vulnérables, rôle des femmes et des jeunes, etc.) et iii) environnementaux (santé humaine, impact des pesticides, dégradation des sols, etc.) et liés au changement climatique. Ce numéro thématique présente des résultats et perspectives de travaux de recherche pouvant contribuer à améliorer la durabilité des systèmes cotonniers en $\mathrm{AOC}$, à ouvrir des pistes vers une transition agro-écologique et à faire face aux nouveaux défis.

Mots clés : Coton / développement rural / agro-écologie / durabilité / Afrique de l'Ouest et du Centre

\section{Introduction}

We talk about an agricultural revolution if, in a given agrarian system, farms progress and adopt new means of

\footnotetext{
$\overline{\text { *Auteur de correspondance }}$ : mamy. soumare@ier.ml
}

production, develop new practices and new crop and livestock systems, and create a new cultivated ecosystem, which leads to the emergence of a new agrarian system (Mazoyer and Roudard, 2000). The impact of cotton in the savannahs of francophone West and Central Africa (WCA) countries has changed the traditional agrarian cropping systems, which included a fallow period, and led to the emergence of new 


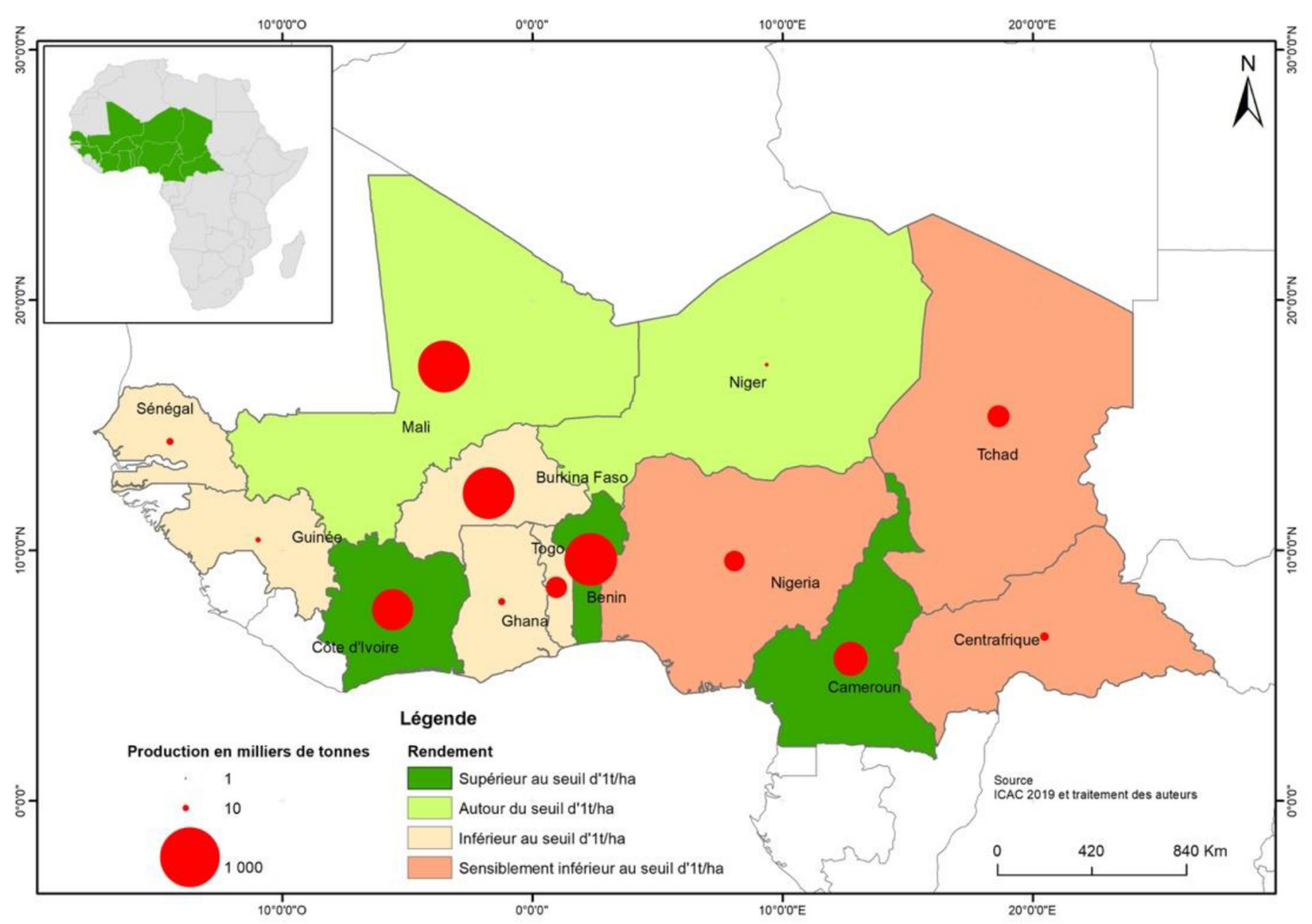

Fig. 1. Production and yield of seed cotton in West and Central Africa.

Fig. 1. Production et rendement en coton graine en Afrique de l'Ouest et du Centre.

agrarian systems. Land is now cultivated continuously and production practices have intensified, particularly input use. The world cotton sector includes over 100 million family farms in 75 countries. However, for many of these farms, cotton is only one element in a complex and integrated farming system (FAO, 2015).

In WCA, the first cotton growing trials were conducted in Senegal in the 1820s (Barry, 2014), and the crop began to develop post World War I (Levrat, 2008; p. 46). Today, African cotton producing countries in the CFA franc zone constitute one of the largest cotton producing zones in the world. According to the International Cotton Advisory Committee (ICAC), they supply from $12-15 \%$ of the world's fiber exports (ICAC, 2019). In 2018-2019, these zones supplied $4.5 \%$ of the 26 million tons of the world's cotton fiber, almost 3.3 million tons of seed cotton (ICAC, 2019). In WCA cotton producing countries, cotton represents $3-15 \%$ of the gross domestic product (GDP) (Planetoscope, 2018). However, production is concentrated in Benin, Burkina Faso, Cameroon, Côte d'Ivoire and Mali. In 2019, annual production ranged from 300000 to 750000 tons of seed cotton in each of these countries, which also have the best yields for rainfed cultivation, with values exceeding 1 ton per hectare (ICAC, 2019) (Fig. 1).

\section{Cotton growing: a key feature of agricultural economies in producer countries in WCA}

The dynamics, which began under colonialism, developed during the period post-Independance, when cotton growing was a key feature of the agricultural and development policies in several WCA countries. It gradually became an essential part of agricultural production and the local economies. Thus, the African cotton growing region in the CFA franc zone saw its share of sub-Saharan cotton production go from $13.5 \%$ in 1970 to around $65 \%$ in 2018-2019 (ICAC, 2019).

The famous quote by René Dumont (1962) "Black Africa got off to a bad start" had a considerable impact and still does. With regard to cotton, Dumont said at the time of Independence: "introducing cash crops (cotton, groundnut) was not a way to modernize farming; on the contrary, it depleted soils". However, the rapid progression of cotton fiber production and its effects on rural development in WCA between 1961 (48 000 tons) and 2004 (1 127000 tons) (ICAC, 2019) make it a rare success in subSaharan Africa. This is shown by the qualifiers illustrating the transformations induced by the crop: "Agricultural revolution", "Success story", "Unmatched development", "Integrated sector promoting the spread of technical progress and innovation", 
"Virtuous circles of progress" (Peltre-Wurtz and Steck, 1991; Bassett, 2002; Devèze and des Fontaines, 2005; Renaudin, 2010).

However, more critical analyses of the cotton sector draw attention to: the crop's negative environmental impacts and the low incomes that family farms earn from it (Pichot et al., 2006); the small percentage of cotton processed in the subregion, the volatility and downward trend of cotton prices, the distortion caused by United States and European subsidies (Nubukpo and Keita, 2006); and producer pesticide poisoning (Westerberg et al., 2017). The security crisis in the 2010s mainly affected the Sahelian zones and cereal production. It had little impact on cotton producing zones in WCA, apart from the significant drop in cotton production in Chad and the Central African Republic. However, the situation is also fragile in the north of Cameroon and the east of Burkina Faso (Commodafrica, 2019; Le Point Afrique, 2019).

\section{Cotton: the driving force of rural development in cotton producing regions in WCA}

In WCA, cotton was grown on the same land for decades and became the powerhouse of crop production, thanks to: i) the commitment of family farms who had access to inputs and seasonal credit, ii) effective support from the technical services, research and producer organizations (PO), but also iii) assertive public policies and, particularly, financial partners, such as the French Economic Cooperation Fund (Caisse Centrale de Coopération Economique, CCCE) in the 1970s, which became the French Development Fund (CFD) in 1989 and then the French Development Agency (AFD) in 2001.

Set up in the 1970s, the organizational model based on the sector's vertical integration was almost the same in all WCA countries. The French textile development company (Compagnie Française de Développement des Textiles, CFDT) was replaced by a national cotton company, which meant the State had a majority stake and the CFDT was a shareholder. This gave rise to Sodécoton, the Cotton Development Corporation in Cameroon, Sofitex, the Burkina Faso Corporation for Textile Fibers, CotonTchad in Chad, etc. In addition to managing the production, ginning and marketing of cotton fiber, these national corporations were assigned rural development missions by the State, which included: i) building the rural tracks required to remove the cotton from the zones of production, ii) organizing literacy classes for producers to facilitate the management of producer associations, iii) supporting animal production by developing cottonseed cake and animal traction, and providing assistance for other crops, introduced as part of a rotation with cotton (maize, millet, sorghum) or to contribute to a balanced diet for farming households (rice). They relied on producer organizations (like the village association in Mali, Association Villageoise), whose role went beyond the sphere of cotton: building classrooms and health centers, village housing, recruiting teachers and health officers, etc. This extract from Soumaré (2008) illustrates the dynamics in Mali: "In the village of Siramana $(30 \mathrm{~km}$ from Sikasso), we attended the relocation of a village site; the first site (former or traditional village) was abandoned definitively for a new site, where the new houses are built with a geometric shape, 'sheet metal' rooves and straight roads. The residents are proud to talk about the change, which was made possible with the money from cotton."

This led to major transformations: the development of animal traction; the intensification of cropping systems using organic manure and mineral fertilizers; the introduction of mixed crop and livestock production, which was possible because income from cotton was invested in livestock; and the emergence of an elite and a smallholder movement with political influence.

\section{The case of Mali, an illustration of the success of cotton}

On a technical level, the number of farms with a full set of animal traction equipment (a pair of draught oxen, a plough, a multipurpose toolbar with hoe and ridging prow) went from $10 \%$ to $95 \%$ between 1970 and 2000 . The number of draught oxen was multiplied by six, from 100000 to 600000 in 30 years (Fig. 2). Cotton production led to the development of cereal crops, like maize. Maize production went from 60000 to over 700000 tons between 1975 and 2018 .

Although, in parallel we might have expected intensive pesticide use, it has remained relatively low, thanks to changes in control methods (staggered targeted control, treatment threshold), used to control parasite pressure (Michel et al., 2000). With the changing crop protection methods, the number of insecticide applications is still 3 or 4 , even after 50 years of cultivation (Castella and Deguine, 2006).

On the economic level, the National Agricultural Development Bank (BNDA) and the micro-finance institution "Kafo Jigine" (the community breadbasket) owe their development to the cotton sector and the management of credits for agricultural equipment and seasonal credits under the impetus of the Malian Textile Development Company (Ouédraogo and Gentil, 2008).

On a social and political level, a number of local councilors and mayors used to hold posts as secretary or leader of the cotton producer associations. Some of them even succeeded in holding a national mandate at the National Assembly and the High Council of Territorial Authorities.

\section{The cotton sector slump and reforms in WCA}

After 30 years of continuous growth, the WCA cotton sector began showing signs of slowing down in the 2000s. This difficult 10-year period, known as the cotton crisis, was caused by: the fluctuations and downward trend on the international fiber markets; the economic collapse of the states and the withdrawal of agricultural subsidies (Gafsi and Mbétid-Bessane, 2003); and structural factors (dysfunctional sectors, management errors) within the cotton companies (Mbétid-Bessane et al., 2010). This crisis was reflected in the low prices for cotton producers, a reduction in the cotton growing areas and lower yields. This led to: a drop in production (by almost $50 \%$ between 2005 and 2008) (Fig. 2); a farmer boycott of cotton growing, as was the case in Mali; a disruption in production and cropping systems linked to the problems of access to inputs and credit; and food insecurity 


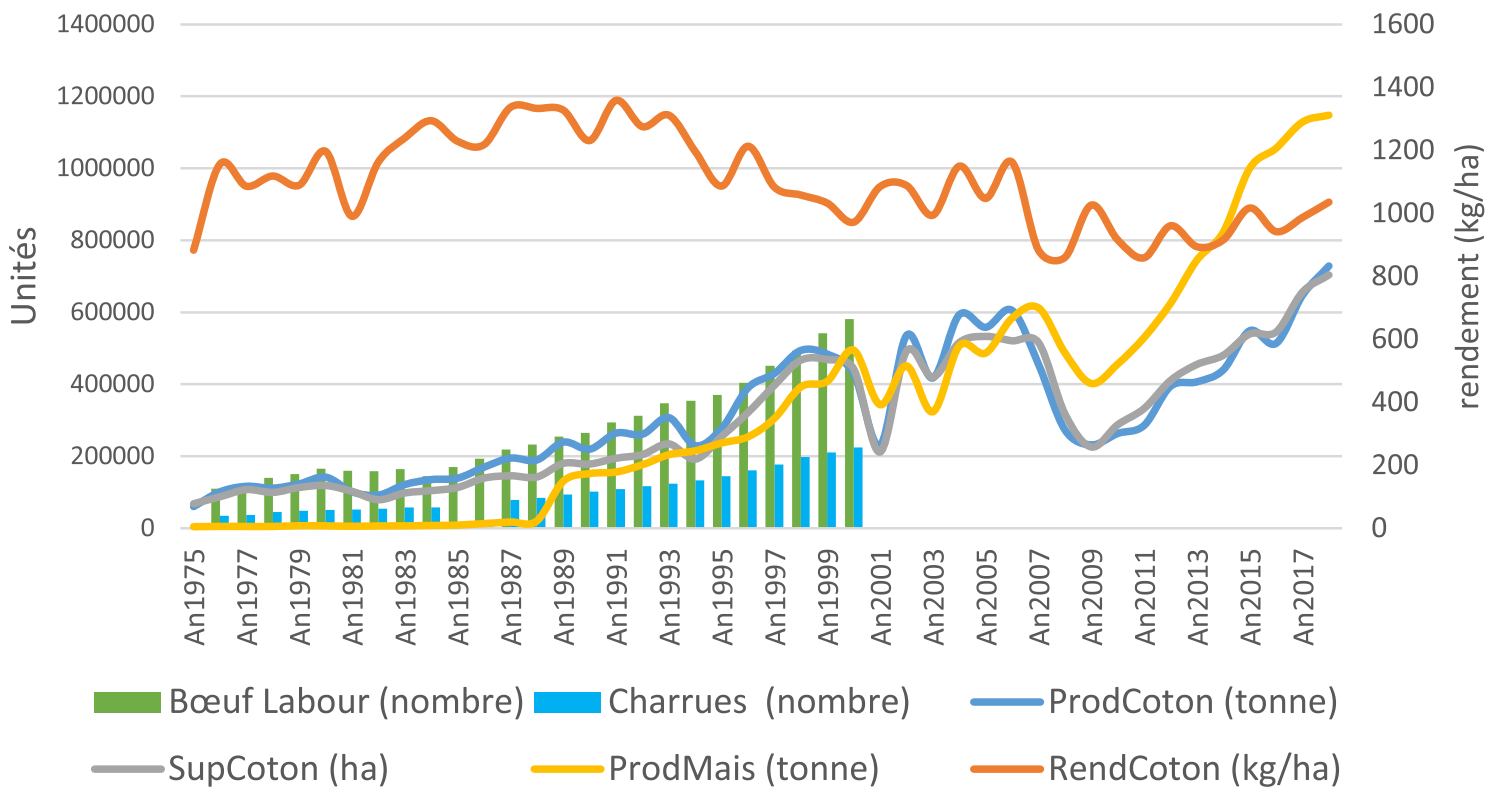

Source : CMDT

Fig. 2. Changes in production, areas, cotton and maize yields and level of farm equipment.

Fig. 2. Évolution des productions, des superficies, des rendements en coton et maïs et du niveau d'équipement des exploitations.

(Folefack et al., 2014). It was also reflected in the cotton companies' major deficits, linked to the fall in world cotton prices and the maintenance of a relatively high price for farmers, and the disarray in African rural areas. "This crisis is particularly serious because it will affect the future of millions of people whose incomes depend directly or indirectly on this crop" (Renaudin, 2010).

In the face of this crisis, numerous and often contradictory solutions were proposed. Two main theories clashed. The financial vision of the Bretton Woods Institutions (the World Bank and the International Monetary Fund, IMF), advocating the privatization and repositioning of cotton corporations, was opposed to a so-called integrated vision, which argued that: the question of cotton in this zone was not merely financial, it was above all economic and social. This stance was adopted by the French Development Agency (AFD) and shared by many countries (e.g. Burkina Faso and Mali, see Box 1 for the case of Mali). However, in Benin, the sector had been liberalized since the 1990s. It no longer involved a unique cotton company, but several actors: ginners, producer unions and input suppliers (Nubukpo, 2011). However, this shift failed to solve the sector's problems (decline in world cotton price, rise in input prices, etc.) and in $2007 / 2008$, the State provided a subsidy to support the producer price (Nubukpo, 2011).

Box 1. Declaration by the Malian President, Amadou Toumani Touré, on the cotton sector reforms

The declarations by the Malian president, Amadou Toumani Touré, quoted by Orsenna (2006), clearly reveal the then rulers' embarrassment: "In 5 years, poverty has declined by $5 \%$ in cotton growing zones and increased by $2 \%$ elsewhere. Today, white gold has become our malediction. Almost a third of our population lives from cotton: 3.5 million men and women! How do you expect us to give up cotton? It is true, I agreed to guarantee farmers a price that is higher than the world price. How could I do otherwise? They were rising up! Is that what the World Bank wants: another unstable zone, in the south of our country, on the borders with Côte d'Ivoire, where refugees are constantly pouring in? How am I supposed to feed them? We are being oppressed because of our deficit, but no one has addressed the root causes of that deficit. For 40 years, day after day, we have struggled to improve. We have done our utmost to play by the rules of competition with no chance of winning because the most powerful player cheats. What can we do about the currency war between Europe and the United States? Through our affiliation to the euro, we are bound hand and foot because cotton is bought in dollars. Do you think that is normal? One of the poorest countries tied to the strongest currency. The more it goes up, the more we fall. No one is protesting and especially not the World Bank." These declarations led the World Bank and the IMF to suspend their support to the Malian government in 2006. A few years later, when the World Bank decided to support agriculture, the Malian President commented ironically "I am glad the World Bank has found me on this path again".

Although not everyone followed the course of total liberalization like Benin, all the cotton producing countries adopted drastic reforms: repositioning cotton corporations 
with regard to cotton production and ginning, reorganizing companies into several companies or subsidiaries, with a reduction in staff and the creation of inter-professional cotton organizations.

In Burkina Faso, the State opened the capital of Sofitex to producers through the National Cotton Producers' Union (UNPC-B). In 2004, Sofitex had to give up two production zones, representing $20 \%$ of national production, to two new corporations, Faso Coton and the Gourma Cotton Corporation (Socoma) (Zoundi et al., 2006; FMI, 2014).

In Mali, the CMDT was split into four production zones, each one organized as a subsidiary with a view to being sold. However, the first calls for tender were unsuccessful. The State continued to support the CMDT and the cotton producers for years, at a cost of several billion CFA francs. The company Dagris (ex-CFDT and now Géocoton) sold its shares to the State of Mali and settled for $0.51 \%$ of the capital. The State then became the main shareholder with $99.49 \%$ of the capital. It then gave $20 \%$ of the capital of each of the four subsidiaries to the Confederation of Cooperative Cotton Producer Corporations (C-SCPC).

The lessons drawn from a World Bank study (Tschirley et al., 2009a; Tschirley et al., 2009b) on the reforms of the organization and performance of the African cotton sector show that greater competition does not necessarily improve sectorial performance and that the role that the public authorities should play depends on international market forces and the cotton sector's internal regulatory mechanism.

\section{Resilience and challenges in the cotton sector in West and Central Africa}

Overall, the cotton sector was able to overcome these difficulties and prove its resilience despite the scale of the crisis in the 2000s. For the last decade, the countries in the CFA franc zone have become actors on the world market once more. Some have beaten or equaled their annual production record: 743000 tons of seed cotton in Mali in 2017-2018 (PR-PICA, 2018), 710000 tons in Burkina Faso in 2014-2015 (Commodafrica, 2015; RFI, 2015) and 720000 tons in Benin in 20182019 (Afcot, 2019).

However, these countries are struggling to maintain their production levels and incomes from cotton in the long term. Burkina Faso's production went from 700000 tons in 2006 to 400000 tons in 2009 (Lankoandé et al., 2011). Since the 2000 s, seed cotton yields have stagnated at around 1 ton per hectare. Incomes from cotton, despite their relative significance, are increasingly failing to meet the monetary requirements of some farming categories, which end up having to borrow at extortionate rates (up to $100 \%$ interest rates) (Sossou and Fok, 2019, in this special issue).

The sustainability of the cotton production systems in WCA is regularly called into question because of their potential negative impact on the environment and human health. For example, in the west of Burkina Faso, over $80 \%$ of soils in the cotton producing systems in Mouhoun are depleted (depletion of substrate with soil loss and decline in soil chemical content) (Hauchart, 2008). In Benin, numerous farmers are poisoned each year by pesticides used on cotton (Westerberg et al., 2017). During the conference Beating
Famine, held from 26th to 28th February 2019 in Bamako, a session organized by the German development agency GIZ (Gesellschaft für Internationale Zusammenarbeit) was entitled "Cotton in West Africa: white gold or cause of soil destruction and environmental damage". Some of these positions are questionable on a scientific level because they tend to rely on local case studies, which means generalizations are limited. However, they call into question the future of cotton's "success story" with regard to contemporary agricultural issues.

In fact, despite the resilience of the African cotton sector, past challenges remain and new ones are emerging: i) the volatility of the price of fiber on the world market, ii) improving and safeguarding producer incomes and well-being in rural communities, iii) the shift in the biological balances and the distribution of biological pests, iv) the reduction in the negative environmental impact of cotton-based cropping systems, by improving soil fertility management, landscape management and reducing pesticide use, v) the political interference in cotton management. Other major challenges that are not specific to cotton-based systems concern agriculture in general: i) developing more ecological practices adapted to the new constraints imposed by climate change, ii) including vulnerable groups in agricultural development dynamics, particularly women and young people, iii) encouraging young people to stay on farms.

In Africa, according to the Intergovernmental Panel on Climate Change (IPCC, 2014), climate change will disrupt temperature, atmospheric $\mathrm{CO}_{2}$ levels and precipitations with an impact on crops (including cotton), particularly in terms of yield, earliness and resistance to pests and diseases. To adapt to these disruptions and mitigate their negative impacts, developing sustainable cotton-based systems (e.g. GMOs, innovations) should help conserve resources and biodiversity. There are several ways to achieve this (Bachelier et al., 2018): i) sustainable land management, using ecological intensification processes for crop and production systems, ii) managing soil organic matter, which affects water retention, erosion and nutrient availability, iii) agro-ecological management of pests and diseases, iv) selecting early varieties, which are compact and resistant to the effects of environmental disturbance.

On small farms in WCA, women do most of the production work, from sowing crops to harvesting (FAO, 2015). This role is seldom recognized or rewarded (ITC, 2011). In the cotton sector, unlike men, women struggle to obtain credit, they are under-represented in the collective organization and exposed to health risks linked to pesticide use (Schneider et al., 2010).

These issues led us to examine how they are tackled (or not) in a number of West African countries. Not all of the challenges are addressed by the articles in this special issue, which follows on from the issue published in 2006 (Cahiers Agricultures, 2006, Special issue: Cotton: building futures https://revues.cirad.fr/index.php/cahiers-agricultures/issue/ view/3297).

\section{Towards more sustainable cotton production systems?}

On an international level, initiatives are underway to evaluate how changing agricultural practices affect the 
sustainability of cotton and to encourage more ecological crop and livestock production systems. The panel SEEP (Social, Environmental and Economic Performance of cotton), created in 2006 under the auspices of the ICAC, developed a list of indicators to measure the sustainability of cotton cropping systems (FAO, 2015). It considers the challenges linked to the management of pests, water and soils, biodiversity and land use, climate change, gender equality and child labor. Various initiatives demonstrate the need and the desire to make current production systems more ecological, for example: the Better Cotton Initiative (BCI) (https://bettercotton.org/about-bci/); the projects that support agro-ecological transition on regional and national scales (Benin, Burkina Faso and Mali); and the creation of environmental departments within the cotton corporations. This goal can be achieved by reducing the use of chemical inputs, promoting agro-ecology and organic crop production, diversifying and using organic products in conventional crop production.

The articles published in this special issue of Cahiers Agricultures focus on the progress made in agriculture, food security and access to education and health (Soumaré et al., 2020). They aim to discuss the improved sustainability of production conditions in cotton systems in WCA and pave the way for an agro-ecological transition in cotton farming.

A number of articles discuss the pest management practices used in production systems with a view to making them more economical in pesticide use, more respectful of human health and the environment and more resilient. There is special emphasis on improving our understanding of the life cycles of pests and their natural enemies (Brévault et al., 2019) with the aim of developing approaches that stimulate ecological processes of natural pest control (Brévault et al., 2019) and reduce pesticide use, e.g. by growing Bt cotton (Vognan and Fok, 2019) or topping (Diarra et al., 2020). It is important to inform, raise awareness and train the actors in the sector to ensure that they know about the environmental and health risks involved in pesticide use (Djagani and Fok, 2019), as well as the good practices to adopt when using pesticides (choice of pesticides, field application, etc.) (Le Bars et al., 2020). This research on cotton pest management shows that pesticide use has been reduced in cotton crops, in Togo between 1990 and 2010, for example (Djagani and Fok, 2019). In contrast, the Ecophyto plan launched simultaneously in France with the same objectives turned out to be a failure (Guichard et al., 2017). Another option for pest control is the use of genetically modified organisms (GMOs), like Bt cotton (incorporating genes from the bacteria Bacillus thuringiensis for resistance to some pests). Vognan and Fok (2019) show that in Burkina Faso, the only country in West Africa to use Bt cotton on a large scale before abandoning it in 2016, the preliminary impacts of this new technology were dependent on numerous factors. The expected results were not necessarily achieved, particularly if the diverse situations and farmer strategies were not considered. In addition, given the risks, which may or may not be verified (biodiversity loss, development of resistance, cost for producers, etc.), the use of GMOs remains controversial, especially in the framework of an agro-ecological transition. It is incompatible with the organic production label. Another possible option is topping cotton. In Mali, the analysis of the producers' perception of topping cotton by hand (Diarra et al. 2020) shows that the technique is easy, reduces flower and capsule drop, makes the plants shorter, improving their spread, and reduces the use and cost of pesticides. However, it increases workload and labor costs.

Other articles in this special issue discuss the sustainability of cotton-based production systems as part of a global approach, at the farm level and regional level. Thus, in the cotton growing zone in Mali, between 1987-2013, the analysis of the agricultural dynamics, food security and access to education and health services in a context of high population growth, shows a gradual net increase in the quantity of cereals produced per person and similar advances in terms of access to education and health infrastructure (Soumaré et al., 2020). Better access to services and the diversification of agricultural activities in the cotton producing zone are factors that are put forward to account for the improvement in the sustainability of farms in this zone. However, the analysis of the cotton producers' liquidity loans in Benin shows that given the cotton production costs and the insufficient public credits, recourse to informal credit operators, who charge extortionate rates, traps farmers in a spiral of debt and poverty (Sossou and Fok, 2019). The analysis of the development of cashew nuts in Côte d'Ivoire reveals that the crop is complementary to cotton growing, less arduous, generates better gross margins and helps transform the agricultural landscape (Koffi and Oura, 2019). Given the high world demand for cashew nuts and the fact that the crop is well adapted to the savannah where cotton is grown, diversifying with cashew nuts could reduce the local economies' dependence on cotton. However, it comes with major risks because it is also subject to the vicissitudes of the world market.

\section{Conclusion}

For several decades, the cotton sector has developed successfully in WCA and managed to overcome crises. However, it is now facing new challenges. Growing cotton, known as "white gold", has been a key element in agricultural economies and has driven rural development in several producer countries. Nonetheless, the sustainability of cottonbased production systems is often called into question because of its impact on the environment and human health, linked to the chemical control of cotton pests. The authors' opinions diverge with regard to the impact that these systems have on soil fertility management. To overcome the crisis in the $2000 \mathrm{~s}$, all the producer countries implemented drastic reforms, which allowed them to overcome the main difficulties and revealed the cotton sector's resilience. Nonetheless, this sector and agriculture in general are faced with major challenges that research should rise to. In the cotton sector, the economic challenges concern: the volatility of prices on the international market; the improvement and safeguarding of producers' incomes and the well-being of rural communities; and the political interferences in the management of the cotton sector. In agriculture in general, which includes the cotton sector, the social challenges concern the inclusion of vulnerable groups in agricultural development dynamics (particularly young people and women) and keeping young people on farms. The environmental challenges include the development of more ecological agricultural practices (reducing soil depletion, 
reducing pesticide use, organic growing, etc.), which are adapted to the new constraints that may be imposed by climate change. The security challenges concern parts of the cotton growing zones in countries like Cameroon, Nigeria and Burkina Faso. In some places, there are problems with field access and clearing produce, which reflect the State's role in rural areas.

\section{References}

Afcot (Association française cotonnière). 2019. Production de coton en Afrique. https://afcot.org/actualites/production-de-coton-en-afri que/.

Bachelier B, Balarabé O, Boulakia S, Demenois J, Gérardeaux E, Goebel F-R, et al. 2018. Which ways forward for sustainable cotton production in Africa in the context of climate change? In: 77th Plenary Meeting of the International Cotton Advisory Committee (ICAC), 2-6 December 2018, Abidjan, Côte d'Ivoire. https:// agritrop.cirad.fr/589934/.

Barry B. 2014. Le royaume du Waalo - Le Sénégal avant la conquête. Ed. Karthala, Coll. Hommes et Sociétés. ISBN 978-2-8111-1243-1, $420 \mathrm{p}$.

Bassett TJ. 2002. Le coton des paysans, une révolution agricole (Côte d'Ivoire 1980-1999). Paris : IRD Éditions, 292 p.

Brévault T, Badiane D, Goebel R, Renou A, Tereta I, Clouvel P. 2019. Repenser la gestion des ravageurs du cotonnier en Afrique de 1'Ouest. Cahiers Agricultures 28. DOI: 10.1051/cagri/2019024.

Castella JC, Deguine JP. 2006. Cycles phytosanitaires et viabilité des systèmes cotonniers. Cahiers Agricultures 15(1): 102-108. https:// revues.cirad.fr/index.php/cahiers-agricultures/article/view/30567.

Commodafrica. 2015. Nouvelle hausse anticipée de la production de coton en Afrique de l'Ouest. http://www.commodafrica.com/ 14-09-2015-nouvelle-hausse-anticipee-de-la-production-de-cotonen-afrique-de-louest.

Commodafrica. 2019. Au nord du Burkina Faso, l'insécurité fait chuter de $70 \%$ la production agricole. http://www.commodafrica. com/29-10-2019-au-nord-du-burkina-faso-linsecurite-fait-chuterde-70-la-production-agricole.

Devèze JC, Halley des Fontaines D. 2005. Le devenir des agricultures familiales des zones cotonnières africaines : une mutation à conduire avec tous les acteurs. À partir des cas du Bénin, du Burkina Faso, du Cameroun et du Mali. Paris : AFD EVA/STR, 85 p.

Diarra M, Havard M, Soumaré M. 2020. La perception des avantages et contraintes de l'écimage du cotonnier par les producteurs du Mali. Cahiers Agricultures 28. DOI: 10.1051/cagri/2020007.

Djagani KK, Fok M. 2019. Dangers potentiels de l'utilisation des insecticides dans la culture cotonnière au Togo de 1990 à 2010. Cahiers Agricultures 28. DOI: 10.1051/cagri/2019023.

Dumont R. 1962. L'Afrique noire est mal partie. Paris, France: Editions du Seuil, $251 \mathrm{p}$.

FAO. 2015. Measuring Sustainability in Cotton Farming Systems. Towards a Guidance Framework. Report. Roma: FAO, ICAC, 149 p. http://www.fao.org/3/a-i4170e.pdf.

Folefack DP, Ntsou Bakwowi J, Kpade PC. 2014. La crise de la filière cotonnière et sécurité alimentaire au Nord Cameroun. Journal of Applied Biosciences 75: 6221-6231.

Fonds monétaire international (FMI). 2014. Burkina Faso, rapport numéro $14 / 230,35 \mathrm{p}$.

Gafsi M, Mbétid-Bessane E. 2003. Stratégies des exploitations cotonnières et libéralisation de la filière. Cahiers Agricultures 12: 253-60. https://revues.cirad.fr/index.php/cahiers-agricultures/arti cle/view/30398.
Guichard L, Dedieu F, Jeufffroy MH, Meynard JM, Reau R, Sayini I. 2017. Le plan Ecophyto de réduction d'usage des pesticides en France: décryptage d'un échec et raisons d'espérer. Cahiers Agricultures 26(1): 14002. DOI: 10.1051/cagri/2017004.

Hauchart V. 2008. Culture du coton, pluviosité et dégradation des sols dans le Mouhoun (Burkina Faso). Sciences et changements planétaires/Sécheresse 19(2): 95-102.

ICAC. 2019. World cotton statistics, December 2019, www.icac.org (accès limité).

Intergovernmental Panel on Climate Change (IPCC). 2014. Fifth Assessment report - Climate change. https://www.ipcc.ch/report/ ar5/syr/.

International Trade Centre (ITC). 2011. Women in cotton: Results of a Global Survey. Geneva: ITC. Xii +23 p. (Technical paper) Doc. No. SC-11-208.E. http://www.intracen.org/uploadedFiles/intrace norg/Content/Exporters/Sectors/Food and agri business/Cotton/ AssetPDF/Women $\% 20$ in $\% 20$ cotton $\% 20-\overline{0} 209 \% 2011 \% 2011 \%$ 20FINAL.pdf.

Koffi YS, Oura KR. 2019. Les facteurs de l'adoption de l'anacarde dans le bassin cotonnier de Côte d'Ivoire. Cahiers Agricultures 28. DOI: $10.1051 /$ cagri/2019025.

Lankoandé GD, Maradan D, Snon K, Thiombiano T, Zine K. 2011. Analyse économique du secteur du coton. Liens pauvreté et environnement. Rapport Final. Genève: Sba Ecosys.

Le Bars M, Sidibé F, Mandart E, Fabre J, Le Grusse P, Diakité CH. 2020. Evaluation des risques potentiels liés à l'utilisation de pesticides en culture cotonnière au Mali. Cahiers Agricultures 28. DOI: $10.1051 /$ cagri/2020005.

Le Point Afrique. 2019. Mali: comment l'insécurité affecte le «grenier à riz» du pays. https://www.lepoint.fr/afrique/malicomment-1-insecurite-affecte-le-grenier-a-riz-du-pays-24-072019-2326615 3826.php.

Levrat R. 2008. Le coton en Afrique Occidentale et Centrale avant 1950. Un exemple de la politique coloniale de la France. Paris, France: Editions l'Harmattan.

Mazoyer M, Roudard L. 2000. Histoire des agricultures du monde, du néolithique à la crise contemporaine. Paris: Editions du Seuil, 705 p. https://www.seuil.com/ouvrage/histoire-des-agriculturesdu-monde-du-neolithique-a-la-crise-contemporaine-marcelmazoyer/9782020323970.

Mbétid-Bessane E, Havard M, Kadekoy-Tigagué D, Djondang K. 2010. Impacts des changements de politique dans un contexte de crise mondialisée sur les acteurs des filières cotonnières d'Afrique Centrale. Cahiers Agricultures 19(1): 21-27. DOI: 10.1684/ agr.2009.0339.

Michel B, Togola M, Téréta I, Traoré Navigué N. 2000. La lutte contre les ravageurs du cotonnier au Mali: problématique et évolution récente. Cahiers Agricultures 9: 109-115. http://revues.cirad.fr/ index.php/cahiers-agricultures/article/view/30228.

Nubukpo K. 2011. L'économie politique de la réforme des filières cotonnières d'Afrique de l'Ouest et du Centre: vers la convergence des modes d'organisation? Mondes en Développement 155(3): 93 109 .

Nubukpo K, Keita MS. 2006. Prix mondiaux, prix au producteur et avenir de la filière coton au Mali. Cahiers Agricultures 15(1): 35 41. http://revues.cirad.fr/index.php/cahiers-agricultures/article/ view/30557.

Orsenna E. 2006. Voyages aux pays du coton, petit précis de mondialisation. Paris : Fayard, 291 p. ISBN 978-2-213-625270.

Ouédraogo A, Gentil D. 2008. La microfinance en Afrique de l'Ouest. Histoires et innovations. Paris, France: Khartala Editions, 308 p. Peltre-Wurtz J, Steck B. 1991. Les charrues de la Bagoué. Gestion paysanne d'une opération cotonnière en Côte d'Ivoire. Paris : IRD, 
305 p. https://www.editions.ird.fr/produit/530/9782709924726/ Les\%20charrues\%20de\%20la\%20Bagoue.

Pichot J, Sédogo MP, Deguine JP. 2006. De nouveaux défis pour la recherche cotonnière dans un contexte difficile. Cahiers Agricultures 15(1): 150-157. https://revues.cirad.fr/index.php/cahiersagricultures/article/view/30574.

Planetoscope. 2018. La production mondiale de coton. https://www. planetoscope.com/agriculture-alimentation/1178-production-mon diale-de-coton.html.

PR-PICA. 2018. Bulletin d'information du PR-PICA, numéro 20 Novembre-décembre. Programme Régional de production intégrée du coton en Afrique. http://prpica.org/IMG/pdf/bulletin_d_in fos_pr-pica_no20_ok.pdf.

Renaudin C. 2010. Les riches heures et l'avenir incertain de la culture cotonnière en Afrique de l'Ouest et du Centre. EchoGeo 14. DOI: 10.4000/echogeo.11955.

RFI. 2015. Après une récolte de coton record, le Burkina réduit ses cultures OGM. http://www.rfi.fr/fr/emission/20150512-apres-unerecolte-coton-record-le-burkina-reduit-cultures-ogm.

Schneider K, Anderson CL, Gugerty MK. 2010. Gender \& Cash Cropping: Cotton in Sub-Saharan Africa. Washington (USA): University of Washington, Evans School of Public Affairs, 11 p. https://evans.uw.edu/sites/default/files/Evans $\% 20$ UW_Request $\%$ 2055_Cotton\%20\%26\%20Gender_18\%20January\%202010.pdf.

Sossou KB, Fok M. 2019. Crédit de trésorerie des producteurs de coton au centre du Bénin: modalités et conséquences. Cahiers Agricultures 28. DO: 10.1051/cagri/2019015.
Soumaré M. 2008. Dynamiques et durabilité des systèmes agraires à base de coton au Mali. Thèse de doctorat unique, Université de Paris X Nanterre, 372 p. http://agritrop.cirad.fr/548140/.

Soumaré M, Traoré S, Havard M. 2020. Croissance démographique, sécurité alimentaire et accès à la santé et à l'éducation en zone cotonnière du Mali. Cahiers Agricultures 29: 36. DOI: 10.1051/ cagri/2020036.

Tschirley D, Poulton C, Labaste P. 2009a. Organisation et performances des filières cotonnières africaines : leçons des réformes (Français). Washington, DC: Banque Mondiale, 223 p. http://documents. banquemondiale.org/curated/fr/355761468003294963/pdf/ 477210PUB0REPL1ch0Edition1Final1PDF.pdf.

Tschirley D, Colin P, Gergely N, Labaste P. Baffes J. Boughton D, et al. 2009b. Méthode d'analyse des effets différentiels des réformes sur les filières cotonnières en Afrique. Cahiers Agricultures 18(5): 385-392. DOI: 10.1684/agr.2009.0334.

Vognan G, Fok M. 2019. Performance différentiée du coton Bt en début de diffusion: cas du Burkina Faso. Cahiers Agricultures 28. DOI: $10.1051 /$ cagri/2019026.

Westerberg V, Golay A, Houndekon V, Costa L. 2017. L'économie de la dégradation de terre, le cas de la commune de Banikoara. Le coton est-il vraiment l'or blanc à Banikoara? GIZ, Economics of Land Degradation (ELD). Disponible sur www.eld-initiative.org.

Zoundi Sibiri J, Hussein K, Hitamana L. 2006. Libéralisation de la filière coton et innovation agricole en Afrique de l'Ouest. Cahiers agricultures 15(1): 17-21. https://revues.cirad.fr/index.php/cah iers-agricultures/article/view/30555.

Cite this article as: Soumaré M, Havard M, Bachelier B. 2020. Cotton in West and Central Africa: from the agricultural revolution to the agro-ecological transition. Cah. Agric. 30: 5. 